PP-293

alpha-1 blocker または TUR-Pによる BPH 症例の Detrusor overactivity およ び Ice water test の反応性について

\section{奈良県立医科大学 泌尿器科}

平山暁秀, 松本 吉弘, 松吉 ひろ子, 山口 旭

大園 誠一郎, 平尾 佳彦

【目的】 Detrusor overactivity（DO）は、BPHにおける刺噋症 状の原因の一つと考えられている。われわれは、BPH 症例に Ice water test（IWT）を行った結果、C fiberを介した反射も 刺激症状の原因のひとつとして示唆されることを過去に報告 した。今回、 alpha-1 blocker $(\alpha \mathrm{B})$ または TUR-Pによる DO およびIWTの反応性について検討した。対象と方法】 BPH と診断した 50 歳以上の男性で、 $\alpha \mathrm{B}$ または TUR-P の治療前後 で pressure flow study および IWT を施行した 56 例を対象と した $(\alpha \mathrm{B}: 26$ 例、TUR-P : 30 例)。治療前後での DO および IWT の反応性を調查するとともに、その反応性に対する影響 因子について検討した。【結果】治療前の DO およびIWT 陽性 例は、各 30 例、18 例であった。 $\alpha \mathrm{B}$ および TUR-P による改善

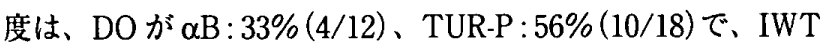
が $\alpha \mathrm{B}: 25 \%$ (2/8)、TUR-P : $90 \%$ (9/10) であり、DOに比較 してIWT の改善率が高く、治療法別では TUR-P の改善率が 高かった。DOの残存例は改善例に比べ治療前の閉塞度が有意 に低く、またIWT の残存例は改善例に比べ閉塞度の改善率が 低かった。結語】DO、IWT 陽性を呈する BPH で閉塞度が低い 症例では、治療後 DO、IWT が残存する可能性が示唆された。

\section{PP-294 前立腺肥大症患者の蓄尿障害に対する 塩酸プロピベリンと $\alpha 1$-blocker 併用投 与の検討}

\footnotetext{
鳥取大学 医学部 腎泌尿器学分野1 国立米子病院 $^{2 !}$ 済生会境港総合病院 ${ }^{3)}$ 公立雲南総合病院4) 博愛病院5) 渡邊 健志", 斎藤 源顕", 平川 真治1, 宮川 征男 ${ }^{11}$ 石田 晤玲 ${ }^{2)}$, 門脇 浩幸 ${ }^{2)}$, 井上 明道 ${ }^{3)}$, 松岡 等 ${ }^{3)}$ 三原 聡"), 山口広司 ${ }^{5)}$

【目的】前立腺肥大症に認められる蓄尿障害に対して, 塩酸プロピベ リンと $\alpha_{1}$-blocker の併用投与を行い, その臨床効果を検討した. 【対 象と方法】 $\alpha_{1}$-blocker が既に1ヶ月以上投与されている蓄尿障害を 訴える前立腺肥大症患者を对象とした，塩酸プロピベリン $10 \mathrm{mg}$ を 2〜4 週間投与し，その前後で I-PSS, QOL-Index, 尿流率, 残尿量 を比較した，尚，本研究は多施設共同で行われた。結果】対象者は 26 名で, 平均年㱓は 68.8 歳, 平均前立腺推定重量は $26.2 \mathrm{~g}$ であった. I.PSS は塩酸プロピベリン投与前で平均 14.0 であったが，投与後で は 9.9 と有意に改善した. 特に排尿間隔のスコアは平均 3.0 から 1.9 , 夜間頻尿は 3.0 から 2.1 と改善した. QOL-Indexでも 3.9 から 2.7 と有意に改善を認めた。最大尿流率は投与前が平均 $10.4 \mathrm{ml} / \mathrm{s}$ で投与 後は $11.2 \mathrm{ml} / \mathrm{s}$ と変化を認めなかった。 また残尿量は投与前が平均 $28.0 \mathrm{ml}$ で投与後は $32.2 \mathrm{ml}$ と増加を認めなかった.【考察】塩酸プロ ピベリンの投与禁忌には下部尿路閉塞が記载されているが, 臨床の 場ではしばしば前立腺肥大症患者に投与されている．今回の結果 は，残尿増加に注意しながらであれば前立腺肥大症の蓄尿障害に対 して塩酸プロピベリンは有用であると示唆された。
}

\section{PP-295 前立腺肥大症に対するナフトピジルの 臨床的有用性の検㢦}

\section{美唄労災病院 泌尿器科}

能中 修,柴田 武, 森田 肇

【目的】前立腺肥大症に対するナフトピジルの臨床的有用 性につき検討を行う。【対象】ナフトピジル 25-50mg/ 日を 4 週間以上投与した前立腺肥大症患者 26 例。年齢は 52-85 歳 (平均 72.1 歳)。【方法】投与前後で I-PSS (閉塞 症状スコア、刺激症状スコア)、QOL スコア、排尿量、最 大尿流率 (Qmax)、平均尿流率 (Qave) 、残尿量、最大 膀胱容量、膀胱コンプライアンス (Cves)、Detrusor Instability（DI）の変化を比較検討した。【結果】投与期間は 4-40 调（平均 11.1 週）。投与前後で I-PSS（前 14.3 後 8.4)、閉塞症状スコア（前 5.5 後 2.8）、刺激症状スコア (前 8.3 後 5.1)、QOL スコア (前 4.3 後 2.6) 、排尿量 (前 $266.1 \mathrm{ml}$ 後 $331.9 \mathrm{ml}$ )、Qave (前 $5.5 \mathrm{ml} / \mathrm{s}$ 後 $6.5 \mathrm{ml} / \mathrm{s}$ ) が有 意に改善した。投与前 DI 陰性例は 15 例、DI 陽性例は 10 例で、DI 除性例では I-PSS、閉塞症状、刺激症状、QOL の各スコア、排尿量、Qave、Qmax が有意に改善した。 DI 陽性例では QOL スコアのみに有意な改善がみられ た。、DI 陽性例のうち 9 例で投与後にDI の消失・軽減 または DI の出現する膀胱容量の増大を認めた。結語】 ナフトピジルは前立腺肥大症患者の自覚所見の改善と、 排尿量、Qave、DI の改善に有用であった。

\section{PP-296}

前立腺肥大症ガイドライン全般度重症 度判定基準別での当院の治療内容の現 況

\footnotetext{
沢村泌尿器科クリニック"大阪市立弘済院付属病院 ${ }^{2)}$ 大阪市立十三市民病院

澤村 新", 河野 学 ${ }^{21}$, 田中 智章 ${ }^{33}$, 桝田 周佳 ${ }^{3)}$

西阪 誠泰 ${ }^{3)}$, 安本 亮二3)

(目的)前立腺肥大症に対する当院での治療内容を、前立腺肥大症がイ ドライン判定基準に準じて検討した。(対象と方法)平成 13 年 12 月か ら平成 14 年 8 月迄の間当院を受診し、前立腺肥大店ガイドライン判 定基準の全ての項目を充たした患者 110 例について检討した。(結 果) 年齢は平均 70.4 歳 (49-95)、前立腺検診回数は 2.6 回 $(1-7)$ 、 IPSS 14.5 点 (1-34)、QOLindex 4.1 点 (0-6) 、 PSA 4. $1 \mathrm{ng} / \mathrm{ml}(0.2-$ $59.5)$ 、前立腺重量 $30.2 \mathrm{ml}(8-118) 、 Q \max 9.3 \mathrm{ml} / \mathrm{sec}(1.7-37.1)$ 、残 尿量 $20 \mathrm{ml}(0-230)$ 、重症度判定で軽症 4 例、中等症 70 例、重症 36 例であった。軽症、中等症、重症の各群で $\alpha 1$ ブロッカー、植物製郕、 漢方薬使用が占める割合は、軽症 $50.50,25 \%$ 中等症 $94,54,33 \%$ 重症 $92.33,61 \%$ と重症になるにつれて漢方薬の占める頻度は增之、漢方投 与群のQOLindexは、改善傾向にあった。漢方薬の内容は駆才血郕 12

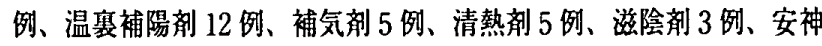
敦 2 桝、気血双補郕 2 例、和解剂 2 例、表裏双解剂 1 例、利水剂 1 例、 その他 1 例であった。なお手術に移行した症例は TUR-bn 1 例のみで あった。(考察)泌尿器科単科開業医にとって前立腺肥大庭患者に対し て内服治療は第一選択であり、患者全身の状態を考慮し体質の改善を 目指寸漢方菜の服用は、臨床上有効と思われた。
} 